\title{
HR Roles in Addressing the Challenges of Industry 4.0: Indonesian Employees Cross- Industry Perceptions
}

\author{
Ester Lisa Mulia The ${ }^{1}$, Anthonius Whisnu Perdana Widiputra ${ }^{2}$, \\ Maria Jacinta Arquisola ${ }^{3 *}$ \\ ${ }^{1}$ Kawan Lama Sejahtera Kembangan, DKI Jakarta 11610, Indonesia \\ ${ }^{2,3}$ President University, Bekasi 17550, Indonesia
}

\begin{abstract}
A B S T R A C T
In light of rapid changes in technology known as Industry 4.0 (IN4.0), this study aims to examine how Indonesian employees perceive the HRM function is being implemented in their organizations using the Ulrich Multiple Roles of HR model, (administrative expert, change agent, strategic leader, employee champion) and whether they believe the HR roles are effective to address the challenges of IN4.0. The study analyzed HR role performance in terms of HRM effectiveness through three variables: HR service, roles, and contributions. Crossindustry data was collected from 160 respondents representing five priority industries: food and beverages, automotive, electronics, textiles, and chemicals. Through descriptive and factor analysis, results show that the HR function in Indonesia is still widely perceived as administrative in nature, and being an agent of change is the least performed HR role. In addition, the results indicated that the HR roles in Indonesia are changing towards a more strategic direction even though the change is slow. HR practitioners must heed the expectations of employees to ensure there are interventions that can be implemented to prepare human capital for IN4.0. Further, the study identified that This is the first type of research that examined how Indonesian employees perceive the HR roles in Indonesian industries are being performed, adding to the scant literature on HR roles in an Indonesian context, and addressing the need for relevant studies on the impact of IN4.0 and HR roles.
\end{abstract}

ART I CLE IN F O

\author{
Article History: \\ Received : 15.11.2019 \\ Revised : :08.02.2020 \\ Accepted : 08.02.2020 \\ Published : 02-03-2020
}

Keywords:

HR Roles,

Effectiveness,

Industry 4.0,

Administrative Expert,

Change Agent,

Strategic Leader,

Employee Champion,

Indonesia.

*Corresponding Author E-mail: mjarquisola@president.ac.id 


\section{INTRODUCTION}

On April 2018, Indonesian President Joko Widodo launched Making Indonesia 4.0, the country's national roadmap for tackling and addressing the demand for skilled workforce in this new era of technological advancement and innovation known as Industry 4.0. This period refers to the current trend of automation and data exchange in manufacturing technologies (Usman, 2018). It is deemed a technological revolution because of its scale and impact, and the way it transforms human activities using automated methods. According to Liffler and Tschiener (2013), the basic principles of IN4.0 is the incorporation of machines, workflows, and systems, by applying intelligent networks along the chain and production processes to control each other independently. Sung (2017) identified the challenges of IN4.0 as follows: a) information technology security issues; b) reliability and stability of production machines; c) lack of adequate skills; d) reluctance to change by stakeholders, and e) the gradual phasing out of human labour due to automation.

This study aims to answer two research questions: How do Indonesian employees perceive the HR roles are performed in their organizations, and which of these HR roles they consider to be effective in addressing the challenges of Industry 4.0 (IN4.0). The study is guided by the Ulrich Multiple Roles model. So far there are limited studies about strategic HR management in Indonesian organizations (e.g. Pranofiani, 2003; Alrosyid, 2003; Hartono, 2010; Rachmi, 2013). The most comprehensive of which was in 1999 (see Habir and Larasati, 1999). In 2003, a study by Bennington and Habir (2003) concluded that HRM studies in Indonesia have been limited particularly for labor economics and the development of macro level human resources. No comprehensive, cross-industry study has been known to date, except in an industryspecific context (see Rachmi, 2013). This study therefore contributes to the limited literature on HR roles in Indonesia by extending the application of the Ulrich model to HR roles in an Indonesian setting, and significant of all, determining the implementation of the HR roles vis-à-vis IN4.0 in the 5 critical sectors identified by the government in its development agenda Making Indonesia 4.0.

In order to address the challenges of IN4.0, countries must produce highly-talented work force. One of the measures for a country's talent competitiveness is the Global Talent Competitiveness Index (GTCI). According to GTCI 2018 reports, six Asia-Pacific countries rank in the top 30: Singapore is first (and second globally), followed by Australia (11th), New Zealand (12th), Japan (20th), Malaysia (27th) and South Korea (30th). Indonesia is now ranked 77th in the world from a total of 119 countries and ranked fourth in the Southeast Asia region. The rating is much lower than neighboring countries such as Malaysia, the Philippines and Thailand.

Global Talent Competitiveness Index 2018: Rankings for Asia pacific

\begin{tabular}{c|l|c|c}
\hline 2 & Singapore & 81 & India \\
\hline 11 & Australia & 82 & Sri Lanka \\
\hline 12 & New Zealand & 87 & Vietnam \\
\hline 20 & Japan & 91 & Bhutan \\
\hline 27 & Malaysia & 93 & Kyrgyzstan \\
\hline 30 & South Korea & 94 & Iran \\
\hline 43 & China & 95 & Lao PDR \\
\hline 51 & Kazakhstan & 108 & Cambodia \\
\hline 54 & Philippines & 109 & Pakistan \\
\hline 70 & Thailand & 114 & Bangladesh \\
\hline 75 & Mongolia & 116 & Nepal \\
\hline 77 & Indonesia & & \\
\hline
\end{tabular}

Figure 1. Global Talent Competitiveness Index 2018 Source: www.gtcistudy.com, 2018

This evidence in Figure 1.1 is telling because Indonesia is one of the world's most rapidly developing economies with a strong and stable democracy. Its inclusion in the G-20 signals strong global recognition for Indonesia's capability to be a world economic leader in the global stage. However, the growth of its economy and global recognition is not matched by the growth of its intellectual and social capital- many Indonesians are still unskilled to meet global competition. Vice President Jusuf Kala stated that in the 
development of IN4.0 the support of good HR is needed, because according to him, the relationship between IN4.0 and HR competency is closely related (Hartomo, 2018). Hence one of the challenges that Indonesia faces is the readiness of human resources. Indonesia is the 4th largest workforce in the world, unfortunately very lacking in talent (Insiderstories.com, 2018). According to data from the Indonesian Ministry of Manpower, $60.24 \%$ (76 million) of its 125.440 million workers are unskilled, having only completed elementary education, and only 11.65 million (9.2\%) are skilled with an undergraduate or Bachelor's degree. There is strong evidence that if workers invest in education increased productivity can be gained from I especially in concrete difference it makes to their salaries (Hendajany, Widodo \& Sulistyaningrum, 2016). According to McKinsey Global Institute (MGI) Indonesia has the opportunity to become the world's seventh largest economy by 2030 and needs skilled laborers around 113 million (www.insiderstories.com, 2018).

The advent of rapid technology and IN4.0 needs greater attention by all stakeholders, in the academic, business and professional industries, and the role of HR in this current landscape calls for it to be more strategic. Significant technological changes related to artificial intelligence and machine learning, for example, will require better change management interventions so the workforce can transition gradually to automation. HRM Managers will be required to manage this disruption and retrain employees to facilitate transitions, particularly given the potential magnitude of future disruptions in the workplace (Montague, 2018). A recent study has suggested that in this age of robotics and artificial intelligence, HR should be one of the most analytical, quantitatively-oriented functions (Davenport, 2019).

\section{LITERATURE REVIEW}

\section{Ulrich Multiple HR Roles}

Ulrich's (1997) multiple role of HR has been found to be one of the most comprehensive models in the HR roles literature, and is frequently mentioned in the HRM based literature (Supuriamaniam, 2012). There are two main dimensions in Ulrich's multiple role frameworks: a) operational focus of HR, and b) the future/strategic focus of HR where the former is focused on managing operational processes, while the latter reflects the conflicting demands of individuals and process (Choi \& Ismail, 2010). According to Supuriamaniam (2012), the multi-role model of HR developed by Ulrich provides HR practitioners with a guide to enable them achieve their strategic roles. See Figure 1. Under Ulrich's model, the strategicallyoriented roles have two important elements: HR as a strategic partner and HR as a change agent. On the other hand, the operationally-focused roles have two important elements: HR as an employee champion, and HR as an administrative expert.

\begin{tabular}{c|l}
\multicolumn{2}{c}{\begin{tabular}{c}
\multicolumn{1}{c}{ FUTURE/STRATEGIC } \\
FOCUS
\end{tabular}} \\
PROCESSES \begin{tabular}{l|l} 
Management of \\
Strategic Human \\
Resources
\end{tabular} & $\begin{array}{l}\text { Management of } \\
\text { Transformation } \\
\text { and Change }\end{array}$ \\
\cline { 2 - 3 } $\begin{array}{l}\text { Management } \\
\text { of Firm } \\
\text { infrastructure }\end{array}$ & $\begin{array}{l}\text { Management of } \\
\text { Employee } \\
\text { Contribution }\end{array}$ \\
DAY-TO-DAY/OPERATIONAL \\
FOCUS
\end{tabular}

Figure 2. Ulrich's Multiple Role Framework Source: Ulrich (1997)

The four roles from this model are discussed below:

\section{Administrative Expert}

This role requires that HR pay more attention to improving the efficiency of the HR function. The role of administrative expert (AE) involves managing daily operational tasks which is argued being performed repeatedly and rarely change (Yusoff, 2012). In this role, HR needs to change their traditional image in the area of making policy while ensuring that all the routine work needed in business is accomplished. In order to move from the previous role as administrators to the new role, HR needs to increase the effectiveness of their function. Salleh, Rosline, \& Budin (2015) conducted a study to investigate the role of HRM and Malaysian skills shortages 
a sample perspective of HR managers in Malaysian organizations of different sizes and in different sectors. These findings reveal that mostly the role as 'administrative experts' played by HR professionals and not as 'strategic business partner' in large companies. Furthermore, there was a lack of skills in accounting, HRM and information technology in the Malaysian labor market. Thus, it was pointed that HR managers in Malaysia were moving towards a more contemporary professional status, but had not really embraced more strategic potential, including enhancing its role in human resource development. It also demonstrated that the development stages of staff development in Malaysia differed by sector, type and organizational ownership. In Indonesia, it is argued that Indonesian HRM is seen as a function of personnel with an administrative orientation (Rachmi, 2013). This means that HRM activities are similar to administrative tasks such as employee record management.

\section{Employee Champion}

Emphasizing Ulrich's model, Hassan, Rahman, \& Yus Kelana (2015) explained the role of employee champion (EC) focuses on employee needs and engaging them to increase their commitment, skills and professional growth. According to Ulrich and Brockbank, this role requires being an "employee advocate" and "human resources developer" (2005 cited in Hassan et al., 2015). As an employee advocate, HR plays an important role in organizational success, uses their experience and knowledge to establish organizational environment where people possess the competency and commitment to perform. Furthermore, becoming the employees' voice means representing their needs and concerns to top management. Basically, HR team should focus on building relationships with managers and employees. In addition, as an employee champion, he/she can persuade and train managers of other departments to spend more time with their employees.

\section{Change Agent}

The focus of this role is to bring transformation and change. HR change agent (CA) must participate to ensure the company has the capability to change. The HR ensures that the company can manage change and also help employees to implement change (Ulrich, 1997 cited in Hassan et al., 2014). Furthermore, as change agent, HR is responsible for the success of transformation and cultural change in organization (Supuriamaniam, 2012). According to Supuriamaniam (2012), the role of HR as change agents implies that he/she must endeavor to facilitate interventions that help solve employee problems as a result of change and integration of change by implementing effective and flexible processes as needed.

Indonesia's employment relations environment, through its labour unions, is observed to be weaker compared to Vietnam although it is argued that the pace and direction of change will differ by country (Collins, Sitalaksmi \& Lansbury, 2013). This situation will have a fundamental effect on how the role as change agent will continue to thrive. For one, HR as a change agent is not an easy role to do, especially if this function is not supported by top leadership. Research by Hinduan, Wilson-Evered, Moss \& Scannell, 2012) found that in Indonesian banks experiencing post-merger, transformational leaders who are more committed and open to change will demonstrate this behavior towards implementing programs that provide opportunities for growth and advancement to employees, creating an impression of stability in post-merger phase. It can be argued that having supportive leaders of this type aid HR change agents' role, as HR is often perceived as an extension of management.

\section{Strategic Partner (SP)}

This role involves facilitating the process of helping identify the company's strategy (Ulrich 1997 cited in Long \& Khairuzzaman, 2008). HR professionals become strategic partners (SP) by asking and planning $\mathrm{HR}$ practices that are effective and efficient which align with the company's strategy. Furthermore, HR professionals must identify and implement practices that will 
support the success of strategic business (Mei \& Subramaniam, 2014). In India, the overall role of $\mathrm{HR}$ in India has transformed from administrative to managerial in some cases, from executives to strategic partners (Nankervis, Rowley, \& Salleh, 2016). HR professionals were becoming aware of the need to align HRM with business needs and strategies to build capacity, resources, competencies, strategies and macro as well as micro HRM activities, which translated into strategic HR roles (Cooke \& Saini, 2010). HR professionals are now increasingly seen as partners in Indian organizations' growth strategies rather than just as administrators (Nankervis et al., 2016). However, in Vietnam, research shows that majority of enterprises changed their personnel functions to 'HR' without changes in their administrative focus or adoption of strategic roles (Warner, 2013; Nguyen, Teo, \& Mylett, 2013); the HR departments' roles are argued to be underdeveloped compared to Western HRM models in Vietnam, India, and Malaysia (Prikshat, Salleh, \& Nankervis, 2016), a claim that may be debated because effective management practices are influenced by both contextual and situational factors (Bartram, 2011 cited in Onnis, 2019) and must not be based on Western models.

\section{HRM Effectiveness}

In the previous studies on the effectiveness of HRM, it is clear that the criteria for assessing the effectiveness of HRM functions differed. Previous studies have measured the effectiveness of the HR department in several ways. Some researchers consider the effectiveness of the HR department as a one-dimensional construct and measure it in relation to the contribution of the HR subunit to the successful implementation of a company's strategies. For example, the concept of "strategic HR effectiveness" examined how the effectiveness of HR is related to the firm financial performance (Kim \& Ryu, 2011). They conducted survey for HR and line executives in order to assess the effectiveness. They divided between the technical and strategic effectiveness of HRM.

Wright, McMahan, Snell, \& Gerhart, (2001) proposed three factors to evaluate the effectiveness of HR management: HR service; roles; and contributions. These indicators measure the effectiveness of human resources in the performance of various roles and the effectiveness of their contribution. The effectiveness of HRM is the value of what human resources practitioners do for the organization and how HRM practices related to the organization's results. Kim (2011) reported that HR executives faced the problem of securing, developing and maintaining human resources as an important issue for conducting day-to-day operations and long-term strategic plans. They found that line executives considered the effectiveness of HR performance significantly lower in the functional field of HR executives. Therefore, they concluded that the human resources department did not meet the performance expectations of line executives.

According to Yusoff, Abdullah, Ramayah (2009) the measure of HRM effectiveness is its contribution. The HR contribution component is evaluated on how the HR function was managed and how it contributed to the company in various dimensions (e.g. how the HR contributed to the company's competitive position, the company's profitability, core competence and human capital). These two aspects of HR effectiveness were used and validated in previous studies (Wright et al., 2001 cited in Yusoff, Abdullah, \& Ramayah, 2009). In their study of Indonesian banks' service level quality, Suhartomo \& Istikomah (2018) found that the reputation of Indonesian banks rely significantly on employee credibility, service quality, and client satisfaction-factors that mirror how the HR roles are implemented effectively, e.g. employee credibility originates from satisfactory training and role preparation in banks; hence a well-trained employee is a credible employee in the eyes of clients. Their study concluded that the best roles in enhancing greater bank reputation was derived from HRM practices for higher employee credibility and HRM practices for higher quality services (p. 403). 


\section{Industry 4.0}

The term Industry 4.0 refers to the fourth industrial revolution characterized by growing trends in the fields of automation, Internet of Things (IoT), Big Data, and Cloud Computing technology. As with earlier versions of steam, electricity, and computers, integration between these technologies will change the industry in the future (Witkowski, 2017). Lee et al (2013) explained that IN4.0 is characterized by an increase in digitalization of manufacturing driven by four factors: First increased data volume, computing power, and connectivity. Second, the emergence of analysis, capability and business intelligence. Third, the occurrence of new forms of interaction between humans and machines. Finally, improvement of digital transfer instructions to the physical world, such as robotics. On the other hand, other challenges include information technology security issues, reliability and stability of production machines, lack of adequate skills, reluctance to change by stakeholders and loss of a lot of work because it changed to automation (Sung, 2017).

The HR profession is acutely aware of the massive challenges that IN4.0 will bring to the workforce. HR operations undergo changes that have never happened before and must respond to it (Bailey \& Welch, 2017). Previous studies have shown that about $40 \%$ of current Australian jobs is likely to be automated in the next 10 to 15 years (Montague, 2018). Digital disruption introduces new realities and new opportunities. New technologies will have a significant impact on how employees work, communicate, respond, and collaborate within and across organizations. The global labor market will be disrupted in the coming years by emerging technologies and its potential to replace human workers. Companies must ensure that they automate the right processes and retrain existing employees in order to develop the skills they need in the future (Kolko, 2018). HR experts are needed to manage this change and respond to the need of employees for higher responsibilities as well as ethical conduct in the use of AI technology (Montague, 2018). In short, companies must ensure that today's workforce is ready for required skills of tomorrow, and if there is a business function that is better suited to tackle this challenge than any other, it is HR (Bhandari \& Chettiar, 2017).

Therefore, in order to understand and analyze the impact of major disruptions on employment levels, such as skill sets and patterns of recruitment in different sectors and countries, HR must be involved in identifying roles that can be automated, and the roles that can be done by humans. For HR leaders, it is necessary to equip their organizations to thrive in this new environment. In order to achieve this, it is time for HR to come out of their traditional way of thinking (Salleh, Rosline, \& Budin, 2015). In Indonesia, the HR role is still perceived to be administrative in orientation (Alrosyid, 2003). HR should be a function that will lead to dynamic transformational changes within an organization, rather than just trying to stay in line with the rest of the company (Business-reporter.com, 2016). Furthermore, HR needs to be analytics-driven where data generated can be used to help business leaders maximize their decision - making outcomes. Cultivating quantitative analysis and reasoning skills, and advising business leaders by telling a story with data rank highly among HR competitive roles (Davenport, 2019).

\section{RESEARCH METHOD}

The respondents in this semi-structured survey were 160 staff employees chosen by purposive sampling. The main criteria used was that the respondent must work in one of the five priority industrial sectors identified by the government as critical sectors for IN4.0. In addition, the respondents must not be staff from HR department, nor were they managers or of supervisory level positions. Respondents were enjoined to give their comments/clarification as they saw fit. Figure 1 shows that $28 \%$ of respondents worked in the automotive industry; $26 \%$ from food and beverage; $19 \%$ from electronics; $14 \%$ from chemicals, and $13 \%$ from textiles.

Table 1. Respondents by Type of Industry

\begin{tabular}{l|c|c}
\hline Industry & Frequencies & Percentage \\
\hline Automotive & 45 & $28 \%$ \\
\hline
\end{tabular}




\begin{tabular}{l|l|l}
\hline Chemical & 22 & $14 \%$ \\
\hline Electronics & 30 & $19 \%$ \\
\hline Food and beverage & 42 & $26 \%$ \\
\hline Textile and apparel products & 21 & $13 \%$ \\
\hline
\end{tabular}

In terms of gender, $52 \%$ were female and $48 \%$ were males. Majority of the respondents (82\%) were in the age range 21-30 years old (millennials), while the rest $(16 \%)$ were aged above 30 years old. As to length of employment, $52 \%$ have worked for $2-5$ years; $27 \%$ less than 1 year, while the rest (21\%) have been employed above 6 years.

Due to the exploratory nature of this study, the researchers decided to establish baseline data of the level of perception by Indonesian employees of the HR roles under investigation. Therefore, a quantitative method utilizing descriptive statistical analysis, and exploratory factory analysis were used to analyze data collected through an online survey. The questionnaire was adopted from Ulrich (1997) and Wright et, al (2001). A pre-test was performed on the questionnaire and distributed to 30 respondents in advance to determine whether the instrument was valid and reliable. Validity test and reliability testswere performed. All questions were valid $(\mathrm{R}=0.361$ at sig 0.05). Cronbach Alpha shows result above $70 \%$ which means the data has high reliability. $(0.70 \leq \mathrm{a} \leq 0.90)$. The result from reliability test shows that all of variable are $>0.60$, meaning all variables are reliable. A fivepoint Likert scale questionnaire was distributed through online using Google Form, a strategy to make it effective and efficient to reach as many respondents. The questionnaire is divided into 4 independent variables which are strategic partner (SP), administrative expert (AE), employee champion (EC) and change agent (CA). Also 1 dependent variable which is effectiveness of HRM.

\section{RESULT}

On the first research question, how do Indonesian employees perceive the HR roles are performed in their organizations, the descriptive statistical analysis shows that Indonesian employees perceive that the HR roles performed in their companies to address the challenges of IN4.0 are still administrative in nature $(\bar{x}=4.02 \sigma=0.39)$, indicating that most respondents agree that this role is the most performed in their company. The second most performed HR role is that of employee champion $(\bar{x}=3.75 \sigma=0.62)$; third is strategic partner $(\bar{x}=3.71 \sigma=0.60)$ while the role of change agent is the least performed role $(\bar{x}=$ $3.62 \sigma 0.84)$.

Respondents believe that HR roles in their company must actually transition from being administrative (regarded as slow in impact) to more strategic. They feel their HR departments spend more time in day-to-day operational issues and administrative processes whereas what is needed is for the function to help management define vigorously business strategies and development programs to face IN4.0. As one respondent commented: Good quality HR is very much needed in dealing with industry 4.0 because in this phase all are very dependent on technology, but how can we control progress if our HR function is still slow? (Respondent\#12)

From the above statement, it can be gleaned that Indonesian employees would like their organizations to be more proactive in finding innovative solutions to the perceived lack of skills in automation and data-driven analysis. A respondent highlighted the value of being innovative in this function, with this comment: Keep on being innovative and always give enthusiasm to its employees, because HRD has an important role to help prosper their employees (Respondent\#25)

Despite the focus on administrative role, the role of employee champion has come out prominently as the second most performed role in Indonesian organizations. Fifty-nine percent (59\%) of employees feel that in order to address the challenges of IN4.0, the HR in their companies must work tirelessly for the economic well-being of employees, while 77 percent believe thatHR spending time to listen and actively respond to employee needs is the HR role most of them desire. 


\section{Factor Analysis}

On the second research questionas to which of these HR roles they consider to be effective in addressing the challenges of Industry 4.0 (IN4.0), Table 2 shows 6 factors which have eigen value more than 1.

From these 6 factors, the researchers decided to choose those dominant factors with Eigen values greater than 2 (Table 3). These two new factors have a $33.65 \%$ cumulative value, meaning that $33.652 \%$ variability of the manifest variables can be explained by these two factors (Table 4).

Table 3. Components, Eigen Value, \%Variance, and Cumulative $\%$

\begin{tabular}{c|c|c|c}
\hline \multirow{2}{*}{ Component } & \multicolumn{3}{|c}{ Initial Eigenvalues } \\
\cline { 2 - 4 } & Total & \% of Variance & Cumulative \% \\
\hline 1 & 5.660 & 23.585 & 23.585 \\
\hline 2 & 2.416 & 10.067 & 33.652 \\
\hline
\end{tabular}

Source: SPSS 20.0 Analysis Output (2018)

Table 4. New Manifest Variables

\begin{tabular}{c|l|l|l|l|l|l|l|l|l}
\hline Factor & \multicolumn{10}{|c}{ Manifest } \\
\hline 1 & SP4 & SP5 & SP6 & CA1 & CA2 & CA3 & CA4 & CA5 & CA6 \\
\hline 2 & EC1 & EC2 & EC3 & EC4 & EC5 & & & & \\
\hline
\end{tabular}

SP - Strategic Partner; CA - Change Agent; EC = Employee Champion

The first factor has $23,585 \%$ of variance after rotation. This factor is a combination of the HR roles 'strategic partner' and 'change agent'. It has been constructed from 9 manifest variables as follows (see Table 5 below):
Based on central tendency measurement statement CA3 has the highest mean (3.76) which emphasizes that HR must be an active participant in organization renewal, change and transformation in industry 4.0, and CA6 statement has the lowest mean (3.56) with statement "HR is seen as change agent". This last statement shows how much employees want the HR to promote change in the organization, consistent with the results of the factor analysis where the first dominant factor expected is that HR must show a combination of the strategic roles and change agent role. This combination of roles is needed to help employees navigate through the demands of advancing technology. Employees see this role as HR being an active participant in organization renewal, change and transformation in industry 4.0. As one respondent commented: $H R$ is currently very crucial in meeting organizational needs, so HR must be willing to learn about existing trends and learn about how these trends impact on our company's business processes (Respondent \# 8)

Employees expect that HR in their organizations will pay more attention to employee skills development which is currently a non-negotiable condition if the organization would like to step up its competitive edge in this IN4.0 era. An effective recruitment and selection strategy aimed at engaging the best talents would draw their organizations closer to addressing the skills gaps required by IN4.0. As commented by one employee: $H R$ have crucial responsibilities in recruiting great

Table 2. Table of Eigen Values

Total Variance Explained

\begin{tabular}{c|c|c|c|c|c|c|c|c|c}
\hline \multirow{2}{*}{ Component } & \multicolumn{4}{|c|}{ Initial Eigenvalues } & \multicolumn{3}{c|}{ Extraction Sums of Squared Loadings } & \multicolumn{3}{c}{ Rotation Sums of Squared Loadings } \\
\cline { 2 - 11 } & Total & \% of Variance & Cumulative \% & Total & \% of Variance & Cumulative \% & Total & \% of Variance & Cumulative \% \\
\hline 1 & 5.660 & 23.585 & 23.585 & 5.660 & 23.585 & 23.585 & 3.795 & 15.805 & 15.805 \\
\hline 2 & 2.416 & 10.067 & 33.652 & 2.416 & 10.067 & 33.652 & 2.738 & 11.408 & 27.214 \\
\hline 3 & 1.998 & 8.324 & 41.976 & 1.998 & 8.324 & 41.976 & 2.604 & 10.852 & 38.066 \\
\hline 4 & 1.739 & 7.246 & 49.223 & 1.739 & 7.246 & 49.223 & 1.937 & 8.069 & 46.135 \\
\hline 5 & 1.590 & 6.625 & 55.847 & 1.590 & 6.625 & 55.847 & 1.875 & 7.811 & 53.946 \\
\hline 6 & 1.076 & 4.482 & 60.329 & 1.076 & 4.482 & 60.329 & 1.532 & 6.383 & 60.329 \\
\hline 7 & .926 & 3.858 & 64.186 & & & & & & \\
\hline 8 & .875 & 3.648 & 67.834 & & & & & & \\
\hline 9 & .828 & 3.450 & 71.284 & & & & & & \\
\hline
\end{tabular}

Source: SPSS 20.0 Analysis Outputs 
Table 5. Manifest Variables by HR Roles - Strategic Partner and Change Agent

\begin{tabular}{|c|c|c|c|c|c|c|c|c|}
\hline No & Variable & Statement & VL & $\mathrm{L}$ & M & $\mathrm{H}$ & $\mathrm{VH}$ & Mean \\
\hline 1 & SP4 & $\begin{array}{l}\text { HR's credibility comes from helping fulfill } \\
\text { strategic goals }\end{array}$ & $1.3 \%$ & $9.4 \%$ & $23.1 \%$ & $48.1 \%$ & $18.1 \%$ & 3.73 \\
\hline 2 & SP5 & $\begin{array}{l}\text { HR develops processes and programmes } \\
\text { to link HR strategies to accomplish } \\
\text { business strategy }\end{array}$ & $0.6 \%$ & $6.9 \%$ & $27.5 \%$ & $50 \%$ & $15 \%$ & 3.72 \\
\hline 3 & SP6 & HR is seen as a business partner & $1.3 \%$ & $11.3 \%$ & $30 \%$ & $35.6 \%$ & $21.9 \%$ & 3.66 \\
\hline 4 & CA1 & $\begin{array}{l}\text { HR helps the organization to adapt to } \\
\text { change in industry } 4.0\end{array}$ & $5 \%$ & $10 \%$ & $21.9 \%$ & $46.3 \%$ & $16.9 \%$ & 3.60 \\
\hline 5 & CA2 & $\begin{array}{l}\text { HR participates in shaping culture } \\
\text { change for renewal and transformation } \\
\text { in industry } 4.0\end{array}$ & $6.3 \%$ & $8.8 \%$ & $22.5 \%$ & $43.1 \%$ & $19.4 \%$ & 3.61 \\
\hline 6 & CA3 & $\begin{array}{l}\text { HR is an active participant in organization } \\
\text { renewal, change and transformation } \\
\text { in industry } 4.0\end{array}$ & $1.9 \%$ & $13.1 \%$ & $16.9 \%$ & $43.1 \%$ & $25.0 \%$ & 3.76 \\
\hline 7 & CA4 & $\begin{array}{l}\text { HR works to reshape behavior for } \\
\text { organizational change }\end{array}$ & $5.6 \%$ & $9.4 \%$ & $22.5 \%$ & $40.0 \%$ & $22.5 \%$ & 3.64 \\
\hline 8 & CA5 & $\begin{array}{l}\text { HR develops process and programmes to } \\
\text { help the organization transform itself } \\
\text { in industry } 4.0\end{array}$ & $2.5 \%$ & $11.9 \%$ & $25.6 \%$ & $45.0 \%$ & $15.0 \%$ & 3.58 \\
\hline 9 & CA6 & HR is seen as change agents & $6.9 \%$ & $13.1 \%$ & $17.5 \%$ & $41.9 \%$ & $20.6 \%$ & 3.56 \\
\hline
\end{tabular}

talents and developing the current employees. They should create programs and become champion or role model for other employees to be ready for Industry 4.0. Because in the end, the one running the company is the human resources (Respondent \#13)

Referring to Table 3, analysis show that the second dominant factor, employee champion, has $10.067 \%$ of variance after rotation. Based on manifest variables, this second dominant factor is about being an employee champion and constructed from 6 manifest variables which are (see Table 6 below):

Consistent with the results of descriptive analysis, being an employee champion is a key HR role that employees expect from their organizations to help them prepare for IN4.0. One employee had emphasized this role, especially noting the importance of ensuring employee satisfaction despite the changes ('HR must be able to hear employee complaints and handle needs appropriately' - Respondent \#86). Further, the employee commented thus: HR tasks nowadays are slowly shifting, with a focus on change management, and slowly changing to industry 4.0, but sometimes $H R$ forgets about employee satisfaction and good industrial relations. HR core tasks must be to balance management aspects with labor aspects (Respondent\#42)

\section{DISCUSSION}

The purpose of this research was to examine how Indonesian employees perceive the HRM function is being performed in their organizations, and which of the HR roles are effective to address the challenges of IN4.0. Based on the analysis, it appears that HR roles in the 5 industries covered in this research are still administrative in nature consistent with findings of previous research (Rachmi, 2013), even though there appears to be change in direction to a strategic role, albeit slowly. In their studies, Rachmi (2013) and Hartono (2010) suggested that one of the reasons for the administrative nature of HR processes in Indonesia lie in the nature of managing businesses in Indonesia - that is, many are family-owned enterprises $(80 \%$ of bis businesses are) whose owners are argued to pay more attention to market access difficulties and financial operations rather than paying little attention to their employees. Indonesian family businesses perform basic personnel functions such recruitment, training, and compensation with limited effort, as seen in textile companies (Rachmi, 2013, p. 54). Family business owners also favor emotional ties 
and closeness, thus ignoring the creation of standardized rules and regulations, clear job descriptions, and policies to invest in empowering and upgrading employee capabilities instead of focusing on family financial gains. This also means that automating HR services could be at the far end of the enterprises' development agenda. There is also a strong element of Indonesian culture embedded in Indonesian enterprises. The national edict of sopan santun and desire for social harmony and order often clash with managers' desire to create and implement change because they do not want to disrupt the social harmony in their workplaces.

The result from this analysis confirms Alrosyid (2003) research which found that while Ulrich multiple HR roles are implemented, the role of administrative expert or taking care of day to day operations is a dominant role. In Malaysia, the same situation holds where most of the roles are 'administrative experts' roles and not as 'strategic business partners' in large companies (Salleh, Rosline, \& Budin, 2015). This finding is in line with the need for a strategy in implementing changes that occur within the organization. In previous research by Yusoff et al (2009), if human resources management plays the role of both strategic partner and change agent, the better HRM contributes to the overall effectiveness of the function, especially in the transformation and cultural change desired by organizations experiencing rapid contextual changes. The role of HR must be a facilitator of change interventions to enable employees cope with change (Supuriamanian, 2012). This new factor is consistent with the results of Pranofiani (2003) who found that the role of $\mathrm{HR}$ as a strategic partner is also influenced by several factors, predominant of which is the role of agents of change. This is not an easy feat to do without the support of leaders (Hinduan, Wilson-Evered, Moss \& Scannell, 2012), while the role of HR as an employee champion and administrative expert would be secondary roles.

Most of the comments from respondents relate to being employee champion and change agents.
From the comments, employees see the contribution of HR role as an employee champion and change agent is very important and needs to be improved. On the other hand, employees perceive these HR roles are needed to address the challenges of IN4.0. Research indicates that HR role is now becoming more complex than ever before due to increasing workplace demands in response to Industry 4.0 in Indonesia. HR therefore must function as a change agent and help their companies adapt to the economic, social and advancing technology challenges. HR practitioners must find and manage the best talents, organize benefits and workplace safety, manage training, resolve conflicts, enforce employment policy and lead the corporate culture and process transformation. The findings in this study are consistent with arguments by Long and Khairuzzaman (2012) and Pranofiani (2003, emphasizing that in times of rapid change, the critical competency skills of HR specialists must revolve around being a change agent in order to add value to the attainment of sustainable competitive advantage. Being a change agent is most important in such critical areas as culture management, effective relationship building, communication skills, performance management, value-chain knowledge, HR technology and conflict management (Ananthram \& Alan, 2013). The role of human resources used to only revolve around HR processes such as recruitment, staffing, training and development, performance updates. HR roles needs to be shifting to a more strategic role in light of the high demands of IN4.0 especially in training and improving employee skills and competencies to manage the expanding tasks that they have, and these tasks are now highly-computerized.

\section{Implications for Managerial Practice}

The 13th HR Expo Confrence \& Exhibition on December 2018 took the theme "Accelerating Strategies to Increase HR Skills in Facing the Industrial Revolution 4.0". It offered seminars and workshops for HR practitioners to increase the resilience of corporate's capability in facing Industry 4.0 as follows: (a) digital transformation in recruitment and selection; (b) training strategy: 
creating agile and high performance talent, compensation strategies to retain best attact and retain the best talent, (c) change and transition management, (d) accelerate human resource management using new digital technologies and (e) empowering the future talent through training and development in digital era. Those are examples of training that should be taken by HR practitioners nowadays to adjust HR role as the company change agent, and become experts in understanding the business strategy and ways to support its implementation. These suggestions to improve HR capabilities are consistent with Kuipers \& Giurge (2017) argument that interventions to improve HR strategies must be aligned in strategic ways with corporate strategies to produce higher organizational performance and results.

\section{CONCLUSION}

HR role is important in every company especially in order to address the challenges industry of rapid technological advancements. In this study, the researchers have shown that most of the HRrolesare still administrative in nature. This is perceived by majority of the respondents as the most performed role, while being a change agent is the least performed role. In this study, employees believe that the dominant roles that need to be improved to address IN4.0 would be a combination of strategic partner and change agent. Based on this research it can be concluded that the shift in the role of HR towards a more strategic direction in IN4.0 needs to improve, even if the progress is slow. Further, this study shows that the changes in the industrial landscape in Indonesia makes for a strong call for $\mathrm{HR}$ management to be involved in organizational strategies that would improve employee competencies, and ensure that the HR processes and programs being pipelined can increase organizational capacity to address the challenges of IN4.0. Indonesian organizations can undertake this transformation by actively offering training programs to understand digital transformation in major areas of $\mathrm{HR}$, for example, recruitment and selection, training for talent management and retention because rapidly advancing technologies also pose a problem for organizations to retain top talents, and provide intensive training to help employees transition from administrative to automated HR systems.

\section{RE F EREN C ES}

Ananthram, S., \& Alan, N. (2013). "Strategic agility and the role of HR as a strategic business partner: An Indian perspective." Asia Pacific Journal of Human Resources, 51,454-470,

Alrosyid, N. H. (2003). Persepsi terhadap upaya transformasi peran SDM menjadi multiple role model. Universitas Indonesia.

Bailey, A., \& Welch, D. (2017, October). Embracing HR Disruption: A Leadership Discussion. Retrieved November 24, 2018, from https://www.bcg.com/publications/2017/human-resources-digitalorganization-hr-disruption-leadership-discussion.aspx

Bartram, T. (2011). Employee management systems and organizational contexts: A population ecology approach. Management Research Review 34(6), 663-677.

Bhandari, A., \& Chettiar, G.K. (2017, March). A New Mandate: The Evolution of Human Resources in Building the Workplace of Tomorrow. Retrieved January 11, 2019, from https://www.spencerstuart.com:443 /research-and-insight/a-new-mandate-the-evolution-of-human-resources-in-building-theworkplace-of-tomorrow

Bennington, L., \& Habir, A. D. (2003). Human resource management in Indonesia. Human Resource Management Review 13(3), 373-392.

Choi, S. L., Ismail, W., \& Khairuzzaman, W. (2010). Readiness of Malaysian human resource professionals to be a strategic partner. Intangible Capital, 6(1), 26-50. 
Collins, N., Sitalaksmi, S., \& Lansbury, R. (2013). Transforming employment relations in Vietnam and Indonesia: Case studies of state-owned firms. Asia Pacific Journal of Human Resources 51(2), 131151.

Cooke, F.L., \& Saini, D. S. (2010) (How) Does the HR strategy support an innovation -oriented business strategy? An investigation of institutional context and organizational practices in Indian firms. Human Resource Management, 49(3),377-400, doi: 10.1002/hrm.20356

Davenport, T. H. (2019). Is HR the most-analytics driven function? Harvard Business Review (Digital Article, April 2019). Retrieved on 19 April 2019 from https://hbr.org/2019/04/is-hr-the-most-analyticsdriven-function.

Global Competitiveness Report 2018 (2018). Retrieved from https://wef.ch/2Px5Veo.

Hartomo, G. (2018). Revolusi Industri 4.0: Wapres JK: Peran SDM Tetap Jadi Inti. Okezone Economy. Retrieved on January 11, 2019, from ttps://economy.okezone.com/read/2018/06/07/320 /1907666/revolusi-industri-4-0-wapres-jk- peran-sdm-tetap-jadi-inti

Hartono, A. (2010). An investigation into strategic human resource management in Indonesia: a grounded research approach (PhD). Murdoch University, Perth, Australia.

HR and the Fourth Industrial revolution. (2016, August 31). Business Reporter. Retrieved on November 24,2018, from https://www.business-reporter.co.uk/2016/08/31/hr-fourth-industrial-revolution

Hassan, M. A., Abu Mansor, N. N., \& Wan Abdul Rahman, W. M. Z. and Yus Kelana, B. (2015). Do line managers have 'linking pin' in HR roles? Intangible Capital,11(1).

Hendajany N., Widodo T., \& Sulistyaningrum, E. (2016). Human capital versus the signaling hypothesis. Journal of Indonesian Economy and Business 31 (2),192-207.

Hinduan, Z., Wilson-Evered, E., Moss, S., Scannell, E. (2012). Leadership work outcomes and openness following an Indonesian bank merger. Asia Pacific Journal of Human Resources, 47 (1), 59-78.

Kim S., \& Ryu, S. (2011). Social capital of the HR department, HR's change agent role, and HR effectiveness: evidence from South Korean firms. The International Journal of Human Resource Management, 22 (8), 1638-1653.

Kolko, J. (2018). 5 Questions We Should Be Asking About Automation and Jobs. Harvard Business Review, December 2018.

Kuipers, B. S., and Giurge, L. M. (2017). Does alignment matter? The performance implications of HR roles connected to organizational strategy. The International Journal of Human Resource Management, 28(22), 3179-3201.

Larasati, A. B., \& Habir, A. D. (1999). Human resource management as competitive advantage in the new millennium: An Indonesian perspective. International Journal of Manpower, 20(8), 548-563.

Lee, J., Lapira, E., Bagheri, B., and Kao, H. A. (2013). Recent advances and trends in predictive manufacturing systems in big data environment. Manufacturing Letters, 1(1), pp.38-41.

Liffler, M., \& Tschiesner, A. (2013). The Internet of Things and the future of manufacturing. Retrieved on 16 August 2018 from https://www.mckinsey.com.

Mei, W., \& Subramaniam, I. D. (2014). A Comparison of the Ability Level of Human Resource Roles and Their Perceived Importance among HR Professionals in the Malaysian Government Linked Companies (GLCs). Asian Social Science, 10(19), 205-217.

Montague, D A (2018). Opinion: HR managers needed to manage digital disruption. Retrieved on November 24, 2018, from https://www.hcamag.com/opinion/opinion-hr-managers-needed-to-managedigital-disruption-249918.aspx

Nankervis, A., Rowley, C., \& Salleh, N. (2016). Asia Pacific Human Resource Management and Organizational Effectiveness: Impacts on Practice. Elsevier Science.

Nguyen, D., Teo, S., \& Mylett, T. (2013). An Exploration of the Roles of HR Departments in Vietnam. Journal of General Management, 39(2),83-113. 
Nurfadilah, P S (2018) Menuju Industri 4.0: Ini 5 Sektor Industri Prioritas Menperin. Retrieved 11 January 2019 from //ekonomi.kompas.com/read/2018/07/24/132835726/menuju-industri-40-ini-5sektor-industri-prioritas-menperin

Onnis, L. A. (2017). Human resource management policy choices, management practices and health workforce sustainability: Remote Australian perspectives. Asia Pacific Journal of Human Resources 57,3-23, doi:10.1111/1744-7941.12159

Policy Review: Preparing Roadmap for Industry 4.0 Era. (2018, March 29). Insider Stories. Retrieved January 11, 2019, from https://theinsiderstories.com/policy-review-preparing-roadmap-forindustry-4-0-revolution-2/

Pranofiani, R. (2003). Analisis Peran Strategik Manajemen Sumber Daya Manusia (MSDM) Pada Perusahaan di Jakarta: Menggunakan Pendekatan Model Dave Ulrich. Universitas Indonesia

Prikshat, V., Salleh, N. M., \& Nankervis, A. (2016). Chapter 6 - An exploratory study of HRM roles and competencies in Vietnam, India and Malaysia. In A. Nankervis, C. Rowley, \& N. M. Salleh (Eds.), Asia Pacific Human Resource Management and Organizational Effectiveness (pp.111-145)

Rachmi, A. (2013). 'The HRM practices of Indonesian medium-sized companies in the textile industry in Java'. DBA thesis, Southern Cross University, Lismore, NSW.

Salleh, N. M., Rosline, A., \& Budin, D. (2015) Human Resource Management Roles \& Skills Shortages in Malaysian Organizations. Scientific Research Publishing.

Sitalaksmi, S., \& Zhu, Y. (2010). The transformation of human resource management in Indonesian stateowned e nterprises since the Asian Crisis. Asia Pacific Business Review, 16(1-2).

Suhartono \& Istikomah, K. (2018). "Human Resources Management Effectiveness for Client Satisfactions and Bank Reputations (Case of State-owned Banks in Indonesia)" In the 2018 International Conference of Organizational Innovation. KnE Social Sciences. doi: 10.18502/kss.v3i10.3390

Sung, T. K. (2018). Industry 4.0: A Korea perspective. Technological Forecasting and Social Change, $132,40-45$.

Supuriamaniam, T. (2012). HR Roles in continuance intention usage towards E-HRM. Universiti Sains Malaysia.

Ulrich, D., Younger, J., \& Brockbank, W. (2008). The twenty-first-century HR organization. Human Resource Management, 47(4), 829-850. Retrieved from https://doi.org/10.1002/hrm.20247

Ulrich, D., Younger, J., \& Brockbank, W. (2013). The state of the HR profession. Human Resource Management, 52(3), 457-471.

Usman, S. (2018). Membangun revolusi industri 4.0 di era digital, ini langkah persiapannya. Merdeka Online. Retrieved January 11, 2019, from https://www.merdeka.com/teknologi/membangun-revolusiindustri-40-di-era-digital-ini-langkah-persiapannya.html

Warner, M. (2013). Comparing human resource management in China and Vietnam: An overview. Human Systems Management, 32(4), 217-229.

Witkowski, K. (2017). Internet of things, big data, industry 4.0-Innovative solutions in logistics and supply chains management. Procedia Engineering, 182, 763-769.

Wright, P. M., McMahan, G. C., Snell, S. A., \& Gerhart, B. (2001). Comparing line and HR executives' perceptions of HR effectiveness: Services, roles, and contributions. Society of Human Resources Management, 40(2), 111-123.

Yusof, Y., M., Abdullah, H. S. \& Ramayah, T. (2009). HR roles effectiveness and HR contributions effectiveness: Comparing evidence from HR and line managers. International Journal of Business and Management, 4(2), 158. 